Acta vet. scand. $1981,22,296-306$.

From the National Veterinary Institute, Uppsala, Sweden.

\title{
THE USE OF FA-TECHNIQUE FOR DETECTING FRANCISELLA TULARENSIS IN FORMALIN FIXED MATERIAL
} A METHOD USEFUL IN ROUTINE POST MORTEM WORK

\author{
By \\ Torsten Mörner
}

\begin{abstract}
MöRNER, TORSTEN: The use of FA-technique for detecting Francisella tularensis in formalin fixed material. A method useful in routine post mortem work. Acta vet. scand. 1981, 22, 296-306. - Tularemia is a highly infectious zoonosis, in Sweden usually occurring in the varying hare. The risk of human infections when diagnosing this disease in the laboratory is high. Therefore, a method for diagnosing tularemia in formalin fixed material with the FA-technique has been tested. 46 necropsied varying hares were examined using this method. 28 of the examined animals were diagnosed with tularemia based on conventional post mortem, histological and bacteriological examinations. 96 per cent of them were positive to the FA-technique test. 18 other animals infected with different bacteria and Toxoplasma were also tested. All the controls were negative.
\end{abstract}

FA-technique; Francisella tularensis; post mortem work; varying hare.

Tularemia occurs in Sweden as an epizootic in the varying hare, Lepus timidus (Borg et al. 1967), but has only seldom been diagnosed in other animals at the National Veterinary Institute.

It is an extremely contagious zoonosis as evidenced by several cases of laboratory-aquired tularemia. It has been reported both in vaccinated and non-vaccinated persons (van Metre et al.1958). The infection dose is very low (Bell et al. 1955) and due to the risks, the handling of infected material should be as restricted as possible. Despite the fact that tularemia is highly infectious to man, the bacteria are difficult to culture on normal agarmedium. The best way to demonstrate the living bacteria is by 
inoculation on living animals, e.g. mice (Karlsson et al. 1973). The demonstration of Francisella tularensis in post mortem material is also connected with several difficulties.

The FA-technique has proved to be a good diagnostic method (Franek et al. 1965, Franek 1965, Karlsson et al. 1970, Karlsson et al. 1973).

One of several advantages with the FA-technique is the possibility to use even highly decomposed material (Hudson et al. 1962, Karlsson et al. 1973), which is of particular interest since tularemia as well as plague from epizootic outbreaks usually have to be diagnosed from a more or less autolytic post mortem material (Quan et al. 1979). The use of fluorescence in the diagnosis of plaque has been demonstrated to be superior to other diagnostic methods (Hudson et al. 1962). When using the FA-technique today impression smears are usually prepared from fresh liver, spleen, and bone marrow tissues and only heat fixed (Franek 1955, Karlsson 1973). When employing this method the risk of contamination is, however, imminent and safer techniques should be developed. It is therefore of interest that White et al. already in 1958 reported that formalin treated material could be used for demonstrating Pasteurella tularensis by the FA-technique. Later also among others, Portman et al. (1976), and Snyder (1979) have been able to demonstrate antigens in formalin fixed material.

Before a method based on such a material could be accepted or rejected in the diagnostic routine its reliability, accuracy and reproducibility have to be carefully examined. The aim of the present investigation therefore has mainly centered on these questions by using old fixed material which could be compared with earlier histological investigations and bacteriological examinations.

\section{MATERIAL AND METHODS}

Material and post mortem techniques

Material from 46 dead varying hares (Lepus timidus) which were sent to the National Veterinary Institute for necropsy from 1967 to 1980 was used in this study. Routine post mortem techniques were applied. Macroscopical lesions were noted. Material from liver and spleen was collected for bacteriological examination. Pieces of tissues - usually from liver, spleen, and bone marrow - were fixed in a $10 \%$ aqueous solution of formalde- 
hyd $\mathrm{pH}$ 4. The fixed material was dehydrated in alcohol and xylene and embedded in paraffin. $2 \mu \mathrm{m}$ thick slides were cut and pasted onto glasses with protein glue. The paraffin was dissolved in xylene and alcohol. The slides were kept unfixed in a moistchamber in a refrigerator.

Slides were stained with hematoxylin and eosin for routine histological examination.

\section{The FA-technique}

Unstained slides from liver, spleen, and bone marrow were treated with different dilutions of rabbit anti-tularemia serum (KA-32 from the National Veterinary Institute). One drop of the diluted serum was placed on the slide. The glass was then placed in a moist-chamber at room temperature $\left(+20^{\circ} \mathrm{C}\right)$ for $45 \mathrm{~min}$. This proved to be better than incubating the sample at $37^{\circ} \mathrm{C}$ for 30 min, while in the latter case the slide "shrank" and it was difficult to read in the microscope.

After treating the slides with anti serum they were washed in PBS $\mathrm{pH} 8.6$ for $15 \mathrm{~min}$. The slides were then stained with sheep FITC-conjugated anti-rabbit serum (from the National Bacteriological Lab, Stockholm), diluted 1:5 (as recommended by the manufacturer) in a moist-chamber at room temperature for $45 \mathrm{~min}$. The slides were then washed in PBS for $15 \mathrm{~min}$ and counter-stained with Ewans blue $0.1 \%$ for 5 min (Nairn 1976). After that the slides were again washed in PBS for $5 \mathrm{~min}$ and mounted with a cover glass and glycerine buffer $\mathrm{pH}$ 8.6. The samples were examined in a Leitz fluorescence microscope with fluorescent attachment incident light after ploem, excitation $\mathbf{4 9 0}$ $\mathrm{nm}$ and emission $530 \mathrm{~nm}$ and magnitude $200 \times$. They were considered positive when there was a bright clear fluorescence distinguished from auto-fluorescence from tissues.

\section{Negative control}

Parallel to the conjugation of the sample with rabbit antitularemia serum, a sample was also conjugated with diluted rabbit serum from a SPF-rabbit of the National Veterinary Institute. This was made with all samples as negative controls. The rabbit-SPF-serum-treated sample was further on prepared as the anti-tularemia-treated sample and examined in microscope. 


\section{Serum dilution test}

\section{RESULTS}

There was a marked difference in the fluorescence between antitularemia and SPF serum (Table 1).

T a b l e 1. Fluorescence test on hare $02209 / 67$ with indirect FAtechnique with different dilutions of anti-tularemia and SPF serum.

\begin{tabular}{lccrcc}
\hline & \multicolumn{2}{c}{ Rabbit anti-tularemia serum } & & \multicolumn{2}{c}{ Rabbit SPF serum } \\
\cline { 2 - 3 } Dilution & Prep-fluoresc. & Auto-fluoresc. & & Prep-fluoresc. & Auto-fluoresc. \\
\hline $1: 2$ & +++ & ++ & & + & ++ \\
$1: 4$ & +++ & + & + & + \\
$1: 8$ & +++ & + & & + & + \\
$1: 16$ & +++ & + & & - & - \\
$1: 32$ & +++ & - & & - & - \\
$1: 64$ & + & - & & - & - \\
\hline
\end{tabular}

$+++=$ strong

$++=$ medium

$+\quad=$ slight

$-\quad=$ no

The clearest fluorescence was obtained from the dilutions $1: 16$ and $1: 32$. The intensity of the auto-fluorescence were low here.

According to this result the dilution 1:20 was chosen for further work.

\section{Necropsy material test}

The difficulties in diagnosing tularemia by means of bacteriological examination has been pointed out earlier. In cases of tularemia according to Borg et al. 1967 there were typical histological lesions with acellular necrosis in the liver, spleen, and bone marrow (Fig. 1). The histological picture was easily distinguished from that of other bacteriological infections.

The correlation between post mortem diagnosis and the bacteriological findings is recorded in Table 2. There was a comparatively low correlation between the number of hares from which Francisella tularensis was isolated and the cases of tularemia diagnosed morphologically. 


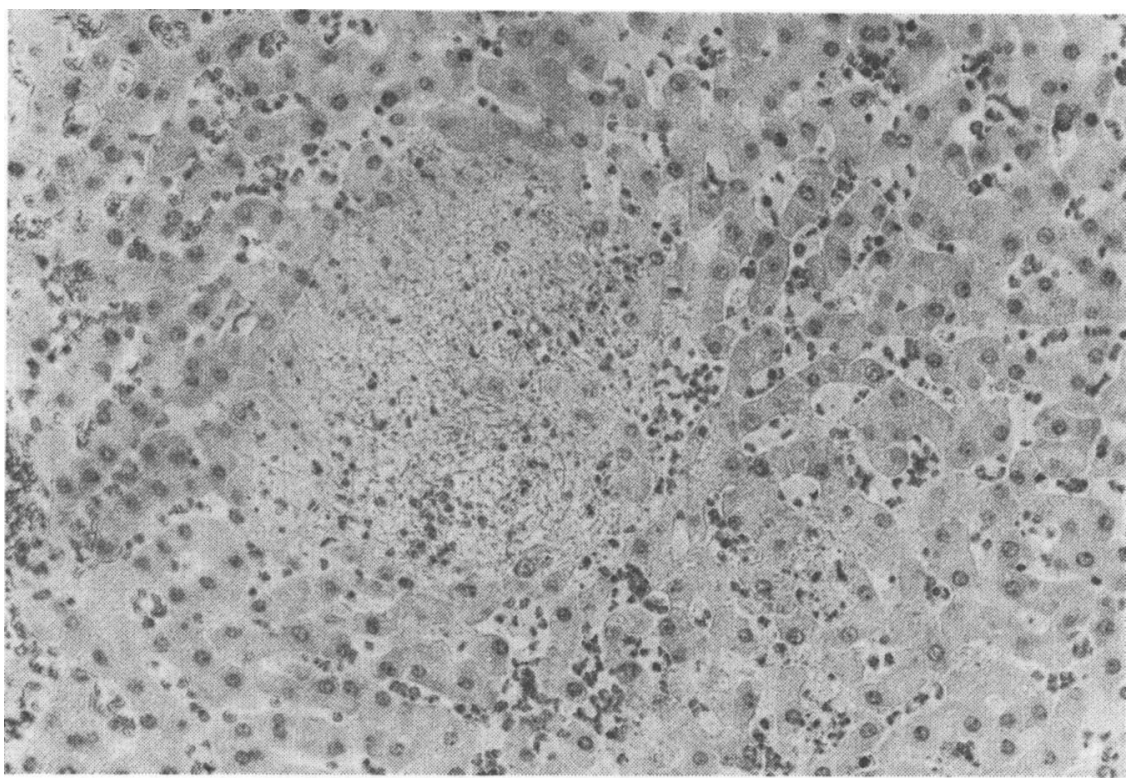

Figure 1. Liver, varying hare, acellular necrosis. $\mathrm{HE} \times 350$.

T a b l e 2. Correlation between post mortem diagnosis and bacteriological findings.

\begin{tabular}{lccc}
\hline Post mortem diagnosis & $\begin{array}{c}\text { Number } \\
\text { of cases }\end{array}$ & $\begin{array}{r}\text { Bacteria } \\
\text { isolated }\end{array}$ & $\begin{array}{c}\text { No bacteria } \\
\text { isolated }\end{array}$ \\
\hline Infection with Francisella tularensis & 28 & 19 & 9 \\
Infection with Salmonella sp. & 3 & 3 & - \\
Infection with Listeria monocytogenes & 5 & 5 & - \\
Infection with Yersinia pseudotb. & 1 & 1 & - \\
Infection with Pasteurella multocida & 2 & 2 & - \\
Toxoplasmosis & 5 & - & 5 \\
Unspecified splenitis & 1 & - & 1 \\
\hline
\end{tabular}

Comparison of post mortem diagnoses and FA-test

The result of this comparison is listed in Tables 3 and 4 . There was a strong correlation between the number of diagnosed cases of tularemia and positive FA-test

The typical histological picture was most often found in the bone marrow and all positive cases investigated (23) had necrotic lesions.

The total number of positive FA-tests was 27 of 28 tularemiacases. 
T a b l e 3. Comparison between typical histology in light microscope and FA-technique.

\begin{tabular}{|c|c|c|c|c|c|c|c|c|c|c|c|c|}
\hline \multirow[b]{3}{*}{ Diagnosis } & \multicolumn{12}{|c|}{ Light microscope } \\
\hline & \multirow{2}{*}{\multicolumn{2}{|c|}{$\begin{array}{c}\text { Total } \\
\text { number }\end{array}$}} & \multicolumn{5}{|c|}{ liver $n=26$} & \multicolumn{3}{|c|}{ spleen $\mathrm{n}=\mathbf{2 8}$} & \multirow{2}{*}{\multicolumn{2}{|c|}{$\begin{array}{c}\begin{array}{c}\text { bone } \\
\text { marrow } \\
n=28\end{array} \\
\text { Necrosis }\end{array}$}} \\
\hline & & & \multicolumn{2}{|c|}{$\begin{array}{c}\text { Necro- } \\
\text { sis }\end{array}$} & $\begin{array}{l}\text { RE-act- } \\
\text { ivation }\end{array}$ & \multicolumn{2}{|c|}{$\begin{array}{l}\text { Serous } \\
\text { hepat. }\end{array}$} & $\begin{array}{l}\text { Necro- } \\
\text { sis }\end{array}$ & \multicolumn{2}{|c|}{ Splenitis } & & \\
\hline \multirow{8}{*}{\multicolumn{2}{|c|}{$\begin{array}{l}\text { Tularemia } \\
\text { Toxoplasmosis } \\
\text { Listeriosis } \\
\text { Salmonellosis } \\
\text { Pasteurellosis } \\
\text { Pseudotuberculosis } \\
\text { Leukosis } \\
\text { Splenitis }\end{array}$}} & 28 & \multicolumn{2}{|c|}{21} & 2 & \multicolumn{2}{|c|}{2} & 22 & & - & \multicolumn{2}{|c|}{23} \\
\hline & & 5 & & 1 & 4 & \multicolumn{2}{|c|}{4} & 1 & & - & \multicolumn{2}{|c|}{ - } \\
\hline & & 5 & & 3 & - & \multicolumn{2}{|c|}{ - } & 1 & & 1 & \multicolumn{2}{|c|}{1} \\
\hline & & 3 & & 1 & - & \multicolumn{2}{|c|}{ 一 } & - & & 1 & \multicolumn{2}{|c|}{1} \\
\hline & & 2 & & 1 & 1 & \multicolumn{2}{|c|}{1} & 1 & & - & \multicolumn{2}{|c|}{1} \\
\hline & & 1 & & 1 & 1 & \multicolumn{2}{|c|}{1} & - & & - & \multicolumn{2}{|c|}{1} \\
\hline & & 1 & & - & - & \multicolumn{2}{|c|}{ - } & - & & - & \multicolumn{2}{|c|}{ - } \\
\hline & & 1 & & & - & \multicolumn{2}{|c|}{ 一 } & - & & 1 & \multicolumn{2}{|c|}{ - } \\
\hline & \multicolumn{12}{|c|}{ Fluorescence microscope } \\
\hline & \multicolumn{4}{|c|}{ liver $n=26$} & \multicolumn{4}{|c|}{ spleen $n=22$} & \multicolumn{4}{|c|}{ bone marrow $n=24$} \\
\hline & & $\begin{array}{l}\text { Inti- } \\
\text { laremi }\end{array}$ & & & $\begin{array}{l}\text { An } \\
\text { tula }\end{array}$ & i- & & $\mathbf{P F}$ & $\begin{array}{r}\text { A } \\
\text { tul }\end{array}$ & laremi & & \\
\hline & + & 一 & + & - & + & - & + & 一 & + & 一 & + & - \\
\hline Tularemia & 22 & 4 & - & 26 & 21 & 1 & 一 & 22 & 23 & 1 & - & 24 \\
\hline Toxoplasmosis & - & 5 & - & 5 & - & 5 & 一 & 5 & 1 & 4 & - & 5 \\
\hline Listeriosis & - & 5 & - & 5 & - & 5 & - & 5 & - & 5 & - & 5 \\
\hline Salmonellosis & - & 3 & - & 3 & - & 3 & - & 3 & - & 3 & 一 & 3 \\
\hline Pasteurellosis & - & 2 & - & 2 & - & 2 & - & 2 & - & 2 & - & 2 \\
\hline Pseudatuber- & & & & & & & & & & & & \\
\hline culosis & 一 & 1 & - & 1 & 一 & 1 & - & 1 & - & 1 & 一 & 1 \\
\hline Leukosis & - & 1 & 一 & 1 & - & 1 & - & 1 & - & 1 & - & 1 \\
\hline Splenitis & - & 1 & - & 1 & - & 1 & - & 1 & - & 1 & - & 1 \\
\hline
\end{tabular}

T a b l e 4. Correlation between diagnosed cases of tularemia and FA-technique test results.

\begin{tabular}{|c|c|c|c|c|c|c|c|c|}
\hline \multirow[b]{2}{*}{ Diagnosis } & \multicolumn{4}{|c|}{ Histological changes } & \multicolumn{4}{|c|}{ FA-test } \\
\hline & Total & $\begin{array}{l}\text { liver } \\
n=26\end{array}$ & $\begin{array}{c}\text { spleen } \\
\mathbf{n}=\mathbf{2 5}\end{array}$ & $\begin{array}{c}\text { bone } \\
\text { marrow } \\
\mathbf{n}=23\end{array}$ & $\begin{array}{l}\text { liver } \\
\mathrm{n}=26\end{array}$ & $\begin{array}{l}\text { spleen } \\
\mathbf{n}=22\end{array}$ & $\begin{array}{c}\text { bone } \\
\text { marrow } \\
\mathbf{n}=\mathbf{2 4}\end{array}$ & $\begin{array}{c}\text { Total } \\
\text { positive } \\
\text { FA-test }\end{array}$ \\
\hline Tularemia & 28 & 21 & 22 & 23 & 22 & 21 & 23 & 27 \\
\hline
\end{tabular}

There was no positive FA-reaction in animals with other infections than tularemia except for one case of toxoplasmosis. In this case the FA-positive necrotic lesions were in the bone marrow. All control samples tested with SPF serum were negative (Figs. $\overline{5}$ and 6 ). 


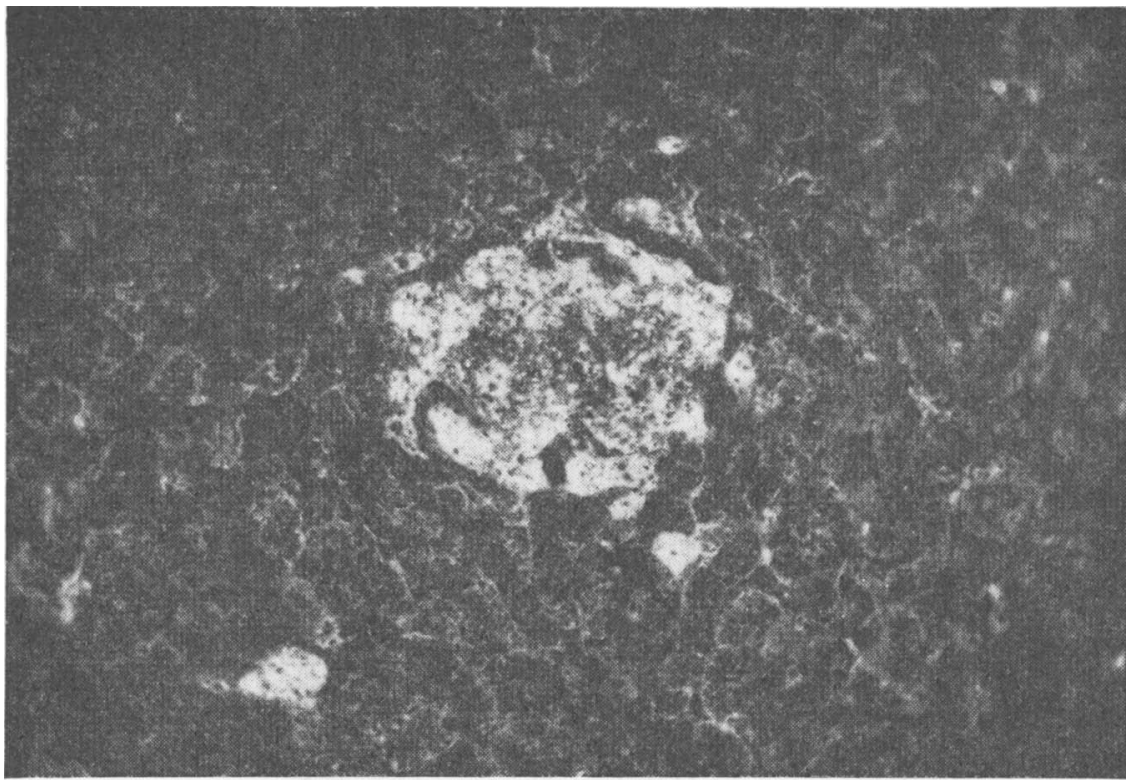

Fi g u r e 2. Liver, varying hare, FA-test, positive reaction. $\times 225$.

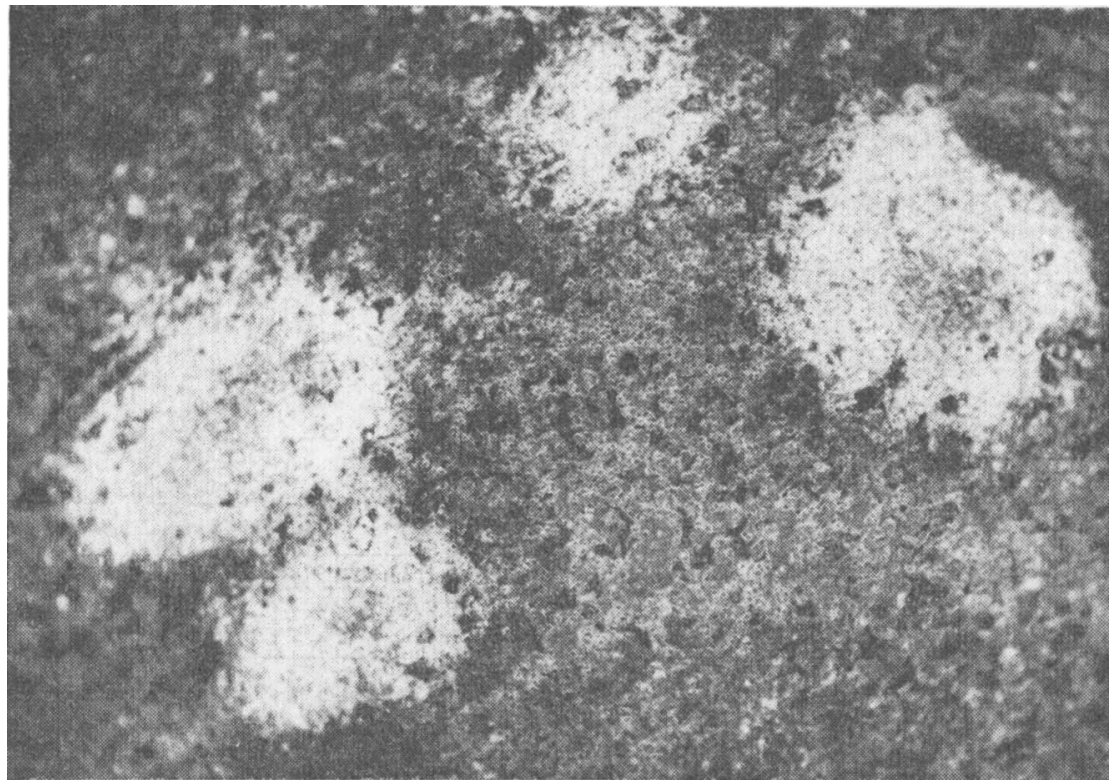

Fig u r e 3. Bone marrow, varying hare, FA-test, positive reaction. $\times 100$. 


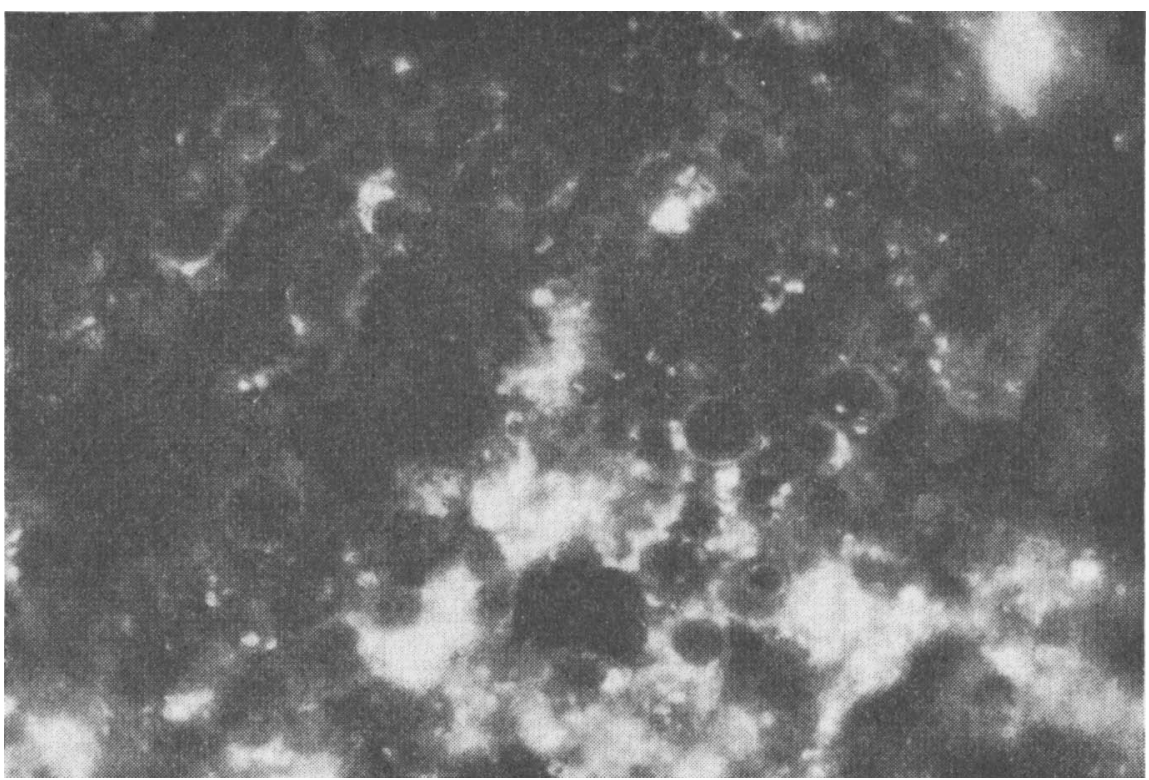

Figure 4. Bone marrow, varying hare, FA-test, positive reaction. $\times 1500$.

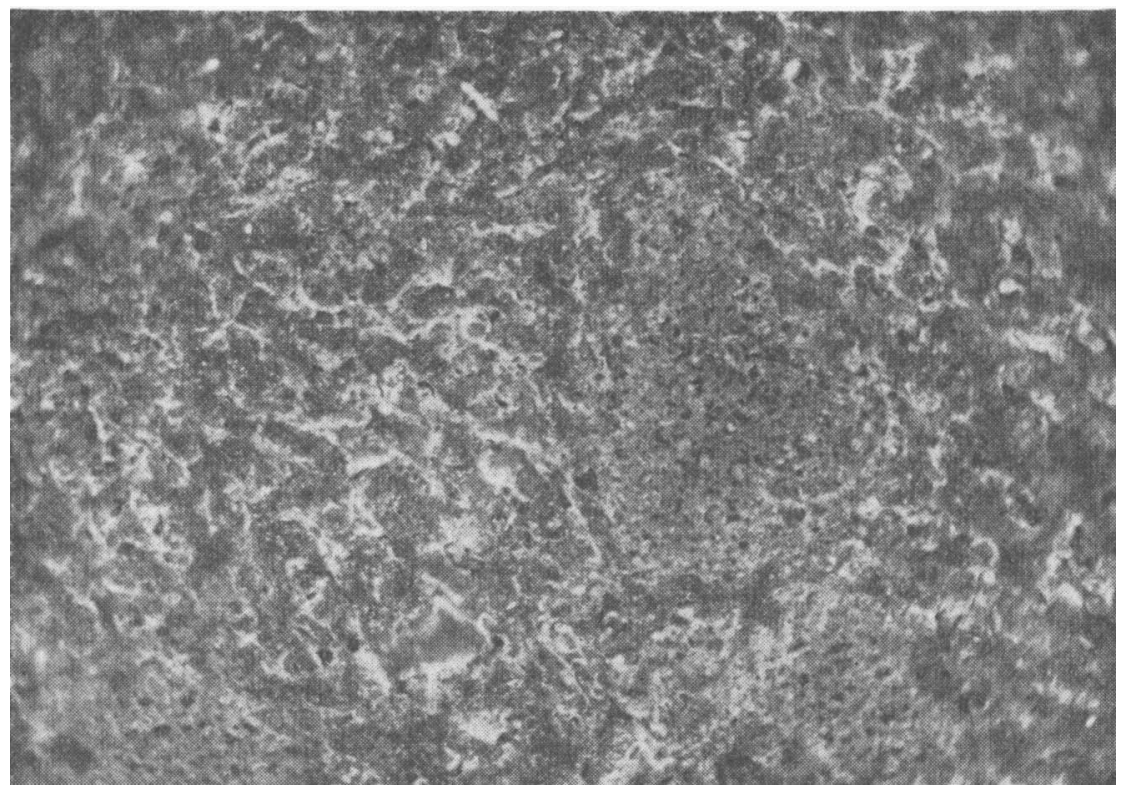

F i g u r e 5. Liver, varying hare, FA-test, SPF control. $\times 225$. 


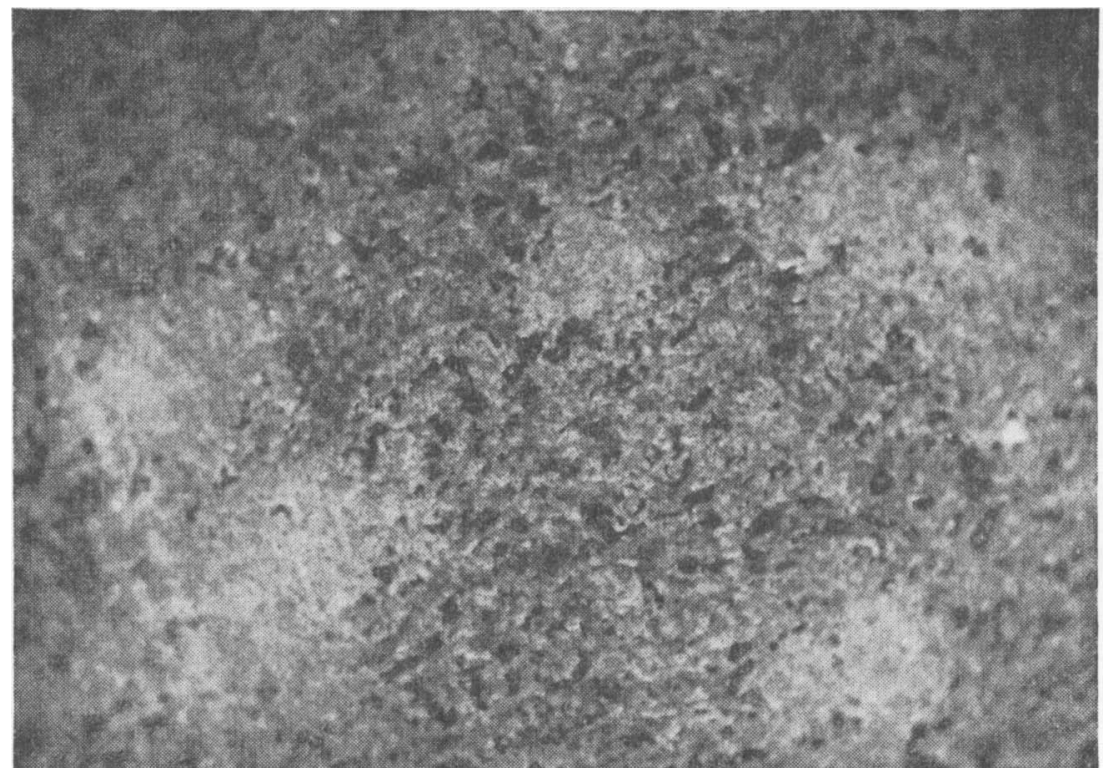

F i g u r e 6. Bone marrow, varying hare, FA-test, SPF control. $\times 100$.

\section{DISCUSSION}

According to Borg et al. 1967, the histological picture of tularemia in infected hares is typical. Acellular necrosis is seen most frequently in the bone marrow and also in the liver and spleen. In this material all the 23 bone marrows examined had typical necrosis as well as $88 \%$ of the spleens and $81 \%$ of the livers. The correlation between the FA-test in different organs and the histological indication of tularemia was high. Thus $96 \%$ of FAtested bone marrows were positive, and $95 \%$ and $85 \%$ of the spleens and livers respectively.

Only one animal morphologically diagnosed as tularemia could not be confirmed by this method. In this particular case the original diagnosis was based on FA-technique on impression smears. The histological picture showed a serous hepatitis without necrosis typical for tularemia. When tested by the method described the liver, spleen, and bone marrow were all negative. The case of toxoplasmosis, positive in the FA-test, is most probably a simultaneous infection with toxoplasma and F. tularensis. The necrotic lesions in the bone-marrow are typical of tularemia in this species, thus providing morphological support for the assumption of a simultaneous infection. 
Out of the 28 investigated animals, bacteria were isolated only from $19(67 \%)$. The difficulties in culturing bacteria from highly decomposed material has been pointed out earlier. In this respect the FA-technique is superior to other methods. It has been shown to be an accurate diagnostic mehod in this type of material (Hudson et al. 1962) and the present work seems to show its validity also as a diagnostic aid for tularemia.

The present work also seems to emphasize the usefulness, accuracy and possibilities of FA-technique on formalin fixed material infected by Francisella tularensis. A great advantage is the high reliability of this method even on a highly decomposed material which normally is highly infectious.

\section{ACKNOWLEDGEMENTS}

I would like to thank Mrs. Lena Johnsson for her skilled technical assistance. Without her help this work had not been possible to do. I would also like to thank Professor Karl Borg, Professor Agnar Nilsson, and Professor Karl-Axel Karlson for their help and advice, and Professor Nils-Erik Björklund for letting me use facilities and equipment of his department. Finally I would like to thank Miss Katarina Bondsäter for typing the manuscript.

\section{REFERENCES}

Bell, J. F., C. R. Owen \& C. L. Larson: Virulence of bacterium tularense in mice, guinea pigs, and rabbits. J. infect. Dis. 1955, 97, 162166.

Borg, K., E. Hanko, T. Krunajevic, N.-G. Nilsson \& P.-O. Nilsson: On tularemia in the varying hare (Lepus timidus). Nord. Vet.-Med. 1969, 21, 95-104.

Franek, J. \& O. Prochazka: Fluorescent antibody demonstration of Pasteurella tularenses. Folia microbiol. (Praha) 1955, 10, 77-84.

Franek, J. \& J. Wolfoua: Use of the immunofluorescence method in an epidemic focus of tularemia. Folia microbiol. (Praha) 1965, $10,85-92$.

Franek, J.: Use of fluorescent antibodies for the rapid diagnosis of infections caused by B. Antracis and P. Tularensis. J. Hyg. Epidem. (Praha) 1965, 9, 160—168.

Hudson, B. W., S. F. Ovan \& L. Kartman: Effacy of fluorescent antibody methods for detection of Pasteurella pestis in carcases of albino laboratory mice stored for various periods. J. Hyg. (Lond.) 1962, 60, 443-450.

Karlsson, K.-A., S. Dahlstrand, E. Hanko \& O. Söderlind: Demonstration of Francisella tularensis in sylvan animals with the aid of fluorescent antibodies. Acta path. microbiol. scand. Sect. B, $1970,78,647-651$. 
Karlsson, K.-A. \& O. Söderlind: Studies of the diagnosis of tularemia. Contribution to Microbiology and Immunology, vol 2: Yersinia, Pasteurella, and Francisiella, 1973, pp. 224-230.

van Metre, T. E. \& P. J. Kadull: Laboratory-acquired tularemia in vaccinated individuals: A report of 62 cases. Ann. intern. Med. $1959,50,621-632$.

Nairn, $R$. C.: Fluorescent Protein Tracing. Churchill Livingstone, 4. ed. 1976, $648 \mathrm{pp}$.

Portmann, B., R. M. Galbraith, A. L. W. F. Eddleston, A. J. Zuckerman \& $R$. Williams: Detection of $\mathrm{HB}_{\mathrm{s}} \mathrm{Ag}$ in fixed liver tissue - use of a modified immunofluorescent technique and comparison with histochemical methods. Gut 1976, 17, 1-9.

Quan, T. J., K.R. Tsuchiya \& L. G. Carter: Isolation of pathogens other than Yersinia pestis during plaque investigations. J. Wildlife Dis. $1979,15,505-510$.

Snyder, R. L.: Hepatitis and hepatocellular carcinoma in captive praire dogs (cynomys ludovicianus) proceedings. Intern. Symp. Diseases in Zoo-animals. Mulhouse 1979, pp. 325-334.

White, S. D. \& G. P. Blundell: The use of the fluorescent antibody technique for demonistration of Pasteurella tularensis in formalin fixed tissues. Bact. Proc. Chicago 1958.

\section{SAMMENDRAG}

Användningen av FA-teknik för att påvisa Francisella tularensis $i$ formalinfixerat material. En användbar metod $i$ rutindiagnostik.

Tularemi är en mycket smittsam zoonos som i Sverige vanligen uppträder hos skogshare. Risken för att laboratoriepersonal skall smittas vid obduktion och diagnostik är stor. Det är därfär önskvärt att kunna diagnostisera sjukdomen på icke smittsamt material. En metod att undersöka formalinfixerat material med hjälp av fluorescentantikroppsteknik har genomförts.

46 harar obducerade vid SVA har ingått i denna studie. 28 av dessa har diagnostiserats som tularemi grundat på patolog-anatomisk bild, histologi och bakteriologi. 27 st $(96 \%)$ av dessa var positiva med FA-testen. Resterande 18 obducerade harar med olika bakteriella infektioner eller infekterade med toxoplasmos testades med FA-testen. Alla fall testade med kontrollserum var negativa.

$$
\text { (Received February 4, 1981). }
$$

Reprints may be requested from: Torsten Mörner, SVA, 75007 Uppsala, Sweden. 